\title{
Free Speech and Intellectual Values
}

\author{
Lee C. Bollinger†
}

In the preface to his book, The Negro and the First Amendment, ${ }^{1}$ Harry Kalven observed that the idea of free speech was marked by an unusually keen "quest for coherent general theory." Every area of the law, Kalven puzzled, was rife with inconsistency and ambiguity, yet inexplicably there was little tolerance for anomalies in the field of free speech. ${ }^{3}$ As to why this was so, Kalven speculated that "free speech is so close to the heart of democratic organization that if we do not have an appropriate theory for our law here, we feel we really do not understand the society in which we live."'

With New York Times Co. v. Sullivan, ${ }^{6}$ Kalven believed that a "coherent general theory" had finally been reached. ${ }^{b}$ In Kalven's view, Justice Brennan's opinion for the Court had for the first time provided our free speech jurisprudence with a "central meaning," identifying a core function of free speech rather than simply repeating, as the cases had so often done, the theoretically empty "clear and present danger" test of Holmes." Kalven thought the Court was in essence pursuing a theory put forward by Alexander Meiklejohn in the late 1940 's, ${ }^{8}$ and, though the Sullivan

$\dagger$ Professor of Law, University of Michigan.

1. H. KALVEN, THE NEGRO AND THE FIRST AMENDMENT (1965).

2. Id. at 4.

3. Kalven noted:

My inquiry is into the impact of the Negro issue on free-speech theory. It presupposes agreement that the quest for coherent general theory in matters of the First Amendment needs no apology and no defense. Yet there is a puzzle here. In general, the law has a great capacity to tolerate inconsistencies; perhaps the most difficult thing for the beginning law student to grasp is this sense of tolerable inconsistency .... To take a page from torts for the moment, if I were to say that my purpose was to struggle with a liability theory that has one basis of liability for industrial accidents and another for non-industrial accidents, or that has one basis for liability in defamation and another for physical harms, you would think I was a purist with unreasonable expectations of generality. When, however, it is, as it will be, a question of fitting control of defamation or obscenity or contempt of court into free-speech notions, we accept the challenge as proper.

Id. at 4-5.

4. Id. at 6.

5. 376 U.S. 254 (1964).

6. Kalven, The New York Times Case: A Note on "The Central Meaning of the First Amendment," 1964 SUP. CT. REV. 191.

7. Id. at 213-14.

8. See A. MEIKLEJOHN, Free Speech and Its Relation to Self-Government, in POLITICAL FREEDOM: The CONSTITUTIONAL POWERS OF THE PEOPLE 3 (1960). Kalven commented:

It is not easy to predict what the Court will see in the Times opinion as the years roll by. It may regard the opinion as covering simply one pocket of cases, those dealing with libel of public officials, and not destructive of the earlier notions that are inconsistent only with the 
opinion nowhere mentioned Meiklejohn or his work, Justice Brennan later subtly agreed with Kalven's attribution. ${ }^{\boldsymbol{1}}$

This triumvirate of New York Times v. Sullivan, Harry Kalven, and Alexander Meiklejohn, which was formed in the mid-1960's, spawned a way of thinking and talking about freedom of speech and press that quickly came to dominate public discourse and continues to do so today. Meiklejohn became the cardinal theorist of this understanding. Many who came after professed to be following in his path. Professor Bork, for example, began his work on the First Amendment with a statement of general allegiance to Meiklejohn's interpretation, ${ }^{10}$ while Professor Bickel claimed to be a member of this tradition in The Morality of Consent. ${ }^{11}$ As I shall show, it is debatable whether these self-proclaimed disciples were true to the faith. At this juncture, I shall confine myself to the observation that Sullivan initiated a major theoretical and idiomatic avalanche, which Meiklejohn was thought to have precipitated.

The essential elements of the Sullivan-Kalven-Meiklejohn paradigm are often difficult to identify. At least two principal themes, however, do appear to emerge from these writings. The first is the notion that the primary function of speech and press is to advance the processes of selfgovernment. The First Amendment must be aligned with the preexisting societal choice of a democratic form of government; it derives its function and legitimacy from serving the process of self-government. And it does this primarily by standing guard against attempts by government to interfere in the self-governing process. The second major theme is the idea that the ultimate aim of the First Amendment is the advancement of the public or collective good and not that of any single individual.

The Sullivan conception of free speech spread through the cases and literature like a grass fire in mid-August. As a result, the First Amendment has become a process-oriented concept, one with all the power and legitimacy of a systemic imperative. Illustrative of this position is Justice Stewart's well-known speech in which he attempts to deal with the prob-

larger reading of the Court's action. But the invitation to follow a dialectic progression from public official to government policy to public policy to matters in the public domain, like art, seems to me to be overwhelming. If the Court accepts the invitation, it will slowly work out for itself the theory of free speech that Alexander Meiklejohn has been offering us for some fifteen years now.

Kalven, supra note 6, at 221.

9. See Brennan, The Supreme Court and the Meiklejohn Interpretation of the First Amendment, 79 HARV. L. REV. 1, 11-19 (1965).

10. See Bork, Neutral Principles and Some First Amendment Problems, 47 IND. L.J. 1, 26 (1971). Professor Bork disagreed with the sweep of protection that Meiklejohn and Kalven would extend under a self-government theory of free speech; he proposed limiting protection to speech that was explicitly "political" in character. Id.

11. See A. BICKEL, THE MORALITY OF CONSENT 62 (1975). 
lem of setting limits on the First Amendment rights of the press. ${ }^{12} \mathrm{He}$ envisions the press as a part of the overall system of checks and balances on institutional power, helping to insure the preservation of democracy. Justice Brennan's concurring opinion in the Richmond Newspapers case ${ }^{13}$ offers another illustration:

But the First Amendment embodies more than a commitment to free expression and a communicative interchange for their own sakes; it has a structural role to play in securing and fostering our republican system of self-government. Implicit in this structural role is not only "the principle that debate on public issues should be uninhibited, robust, and wide-open," but also the antecedent assumption that valuable public debate-as well as other civic behavior-must be informed. The structural model links the First Amendment to that process of communication necessary for a democracy to survive, and thus entails solicitude not only for communication itself, but also for the indispensable conditions of meaningful communication. ${ }^{14}$

Here, as with Stewart's perspective, the analysis of the boundaries and meaning of the First Amendment is demarcated by talk of limiting political power, by checks and balances, and by arguments for the creation of the efficient flow of information necessary for democracy to function. This is the method of discourse so powerfully initiated by the Sullivan decision.

Despite its dominance, the Sullivan idiom has met with a growing undercurrent of dissatisfaction. ${ }^{15}$ The objections commonly offered seem to be of two varieties. One concern is that linking the First Amendment with

12. See Stewart, Or of the Press, 26 Hastings L.J. 631, 633-34 (1975) ("IT]he Free Press guarantee is, in essence, a structural provision of the Constitution . . . The primary purpose of the constitutional guarantee of a free press was . . to create a fourth institution outside the Government as an additional check on the three official branches."); see also Address by William J. Brennan, Jr., 32 RUTGERS L. REV. 173, 176 (1979) ("The First Amendment protects the structure of communication necessary for the existence of our democracy.").

13. Richmond Newspapers, Inc. v. Virginia, 448 U.S. 555 (1980).

14. Id. at 587-88 (Brennan, J., concurring) (citations and footnotes omitted).

15. Professor Tribe, for example, urges a more balanced view of the "purposes" of the First Amendment, claiming that the "instrumentalist" vision of free speech, which sees free speech as a means to a systemic end, whether it be truth generally or good political decisions, fails to recognize that liberty of speech is also an end in itself. Speech, in this latter view, permits each individual the meaningful freedom to express himself as he feels the need to do so: "What, finally, of speech as an expression of self? As a cry of impulse no less than as a dispassionate contribution to intellectual dialogue?" L. TRIBE, AMERICAN CONSTITUTIONAL LAW § 12-1, at 577 (1978). He adds: "More generally, it must be said that Meiklejohn's conception of the First Amendment, and Holmes', were both far too focused on intellect and rationality to accommodate the emotive role of free expression-its place in the evolution, definition, and proclamation of individual and group identity." Id. at 578; see also B. SCHMIDT, FREEDOM OF THE PRESS V. PUBLIC ACCESS 31-36 (1976) ("[T] the tradition of the First Amendment . . . define[s] a scope for the Amendment that is not instrumental, not designed to shape the political process, and not a policy of efficiency in democratic self-governance."); Dworkin, Is the Press Losing the First Amendment?, N.Y. REV. BOOKS, Dec. 4, 1980, at 49, 55-56 (discussing whether free speech is directed toward protection of the speaker or the listener). 
the system of self-government will yield a theory of protection that is too narrow in scope..$^{16}$ Along this line, some argue that if only the speech needed for political decisionmaking is protected, other speech, equally worthy of protection when measured on a scale of general importance to society, will then be suppressed. Alternatively, others argue that even speech that cannot necessarily be said to be in the public interest should be sheltered against censorship. ${ }^{17}$

The second critique of the linkage between the First Amendment and the public interest in self-government expresses concern about that link's stability. Some have worried about the possibilities for manipulation, or cowardice in the face of manipulation, when the scope for protection is based on such an indeterminate concept as the public interest. Or it may be feared that thinking about free speech in such general terms may lead people to accede more readily to that persistent temptation to tinker with First Amendment rights on some disingenuous notion that systemic needs either no longer make it possible to accommodate those rights or permit only a much modified version of them. ${ }^{18}$

16. See L. TRIBE, supra note $15, \S 12-1$.

17. Discussing the cases involving the rights of the press under the First Amendment, Dworkin says that the "dominant theory among American constitutional lawyers assumes that the constitutional rights of free speech-including free press . . . are directed at protecting the audience." Dworkin, supra note 15, at 51 . Such a theory, he observes, is generally defended on the ground of "policy":

They argue, that is, that a reporter must have certain powers, not because he or anyone else is entitled to any special protection, but in order to secure some general benefit to the community as a whole, just as farmers must sometimes have certain subsidies, not for their own sakes, but also to secure some benefit for the community.

Id. Dworkin objects that "[i]f free speech is justified as a matter of policy, then whenever a decision is to be made about whether free speech requires some further exception or privilege, competing dimensions of the public's interest must be balanced against its interest in information." Id. at 52. He says:

Suppose the question arises . . . whether the Freedom of Information Act should be amended so that the Disease Control Center is not required to make its reports available to reporters, or whether the Atomic Energy Commission should be allowed to enjoin a magazine from publishing an article that might make atomic information more readily available to foreign powers. In both cases the "public's general interest" cuts in two directions, in "being well informed" and in having "infection-free hospitals" and "atomic security." This means that a "cost-benefit analysis" must be introduced, and it may well be decided that "in the long term (and taking side effects into account) the public would lose more overall if the information in question were published." "Then," Dworkin concludes with unexceptionable logic, after having defined "interest" as encompassing only an interest in being well informed, "it would be self-contradictory to argue that it must be published in the public's interest, and the argument for free speech, on grounds of policy, would be defeated." Id.

Professor Tribe advances another objection to the self-government rationale. Such a rationale, he says, really only provides an intermediate purpose for the First Amendment, one that leads ultimately to an individual autonomy or self-realization goal. If you ask why self-government should be valued, the common answer will be "that political participation is valuable in part because it enhances personal growth and self-realization." L. TRIBE, supra note $15, \S 12-1$, at 578 .

18. These kinds of concerns have developed especially in two areas of the First Amendment: broadcast regulation, where a public interest approach has been particularly prominent in upholding government regulation; and press access, where it has been argued that the press should be accorded certain special First Amendment rights on the ground that such rights would advance the public interest. See Red Lion Broadcasting Co. v. FCC, 395 U.S. 367, 386-401 (1967) (broadcasters have 
Any critic, of course, must supply an alternative vision. Typically, the competing theory involves some variation on the theme of free speech as the protector of the individual interest, defined in terms such as "selfrealization," or "autonomy," or inherent rights of equal political participation. ${ }^{19} \mathrm{~A}$ few cases, like Cohen v. California, ${ }^{20}$ and a few judicial opinions, like Justice Brandeis' concurrence in Whitney v. California, ${ }^{21}$ are frequently cited as speaking to this alternative notion of the root principle of the First Amendment. ${ }^{22}$

I share the feelings of uneasiness about the dominant systemic perspective, although I do not believe that the individual rights or autonomy perspective provides an entirely satisfactory alternative for explaining what is done in the name of free speech. Often, the rights perspective seems to be simply a way of avoiding having to explain why particular speech activities ought to receive protection; as such it is both unhelpful as a method of solving the practical questions with which the First Amendment must grapple, and unlikely to prove durable. ${ }^{23}$ When reasons are given to sup-

affirmative duty to present both sides of political issues and to allow responses to personal attacks); Columbia Broadcasting Sys., Inc. v. Democratic Nat'l Comm., 412 U.S. 94, 141-44 (1973) (Stewart, J., concurring) (discussing "public interest" in broadcast regulation); Lewis, A Preferred Position for Journalism?, 7 HOFSTRA L. REV. 595 (1979) (considering claims for preferential status for the press).

19. See L. TRIBE, supra note $15, \S 12-1$. Dworkin argues for a view of free speech as protecting the rights of the speaker against any of several possible harms of censorship, a theory premised on the belief

that censorship is degrading because it suggests that the speaker or writer is not worthy of equal concern as a citizen, or that his ideas are not worthy of equal respect; that censorship is insulting because it denies the speaker an equal voice in politics and therefore denies his standing as a free and equal citizen; or that censorship is grave because it inhibits an individual's development of his own personality and integrity.

Dworkin, supra note 15, at 51; see also Scanlon, $A$ Theory of Freedom of Expression, 1 PHIL. \& PUB. AFF. 204, 215-20 (1972) (extrapolating from Meiklejohn that our interest in autonomy mandates restricting government from forbidding speech merely because citizenry might come to believe ideas expressed).

20. 403 U.S. 15 (1971).

21. 274 U.S. 357,372 (1927) (Brandeis, J., concurring).

22. Justice Harlan's opinion for the Court in Cohen is the most famous of such decisions:

The constitutional right of free expression is powerful medicine in a society as diverse and populous as ours. It is designed and intended to remove governmental restraints from the arena of public discussion, putting the decision as to what views shall be voiced largely into the hands of each of us, in the hope that use of such freedom will ultimately produce a more capable citizenry and more perfect polity and in the belief that no other approach would comport with the premise of individual dignity and choice upon which our political system rests.

403 U.S. at 24. Another opinion thought to be in this vein is Buckley v. Valeo, 424 U.S. 1 (1976) (per curiam). See also Polsby, Buckley v. Valeo: The Special Nature of Political Speech, 1976 SUP. CT. REV. 1, 13-14 (interpreting Buckley v. Valeo as embracing "individual right" perspective of First Amendment).

23. Zechariah Chafee captured the difficulty of thinking exclusively in terms of rights:

[I]t is useless to define free speech by talk about rights. The agitator asserts his constitutional right to speak, the government asserts its constitutional right to wage war. The result is a deadlock. Each side takes the position of the man who was arrested for swinging his arms and hitting another in the nose, and asked the judge if he did not have a right to swing his arms in a free country. "Your right to swing your arms ends just where the other man's nose begins." To find the boundary line of any right, we must get behind rules of law to human 
port a rights analysis it is usually said that the interests of the speaker are sufficiently great that the society ought to let him proceed undisturbed. Such an argument, however, is just another way of saying that the community is better off by the speech being protected, because to do what is right is to be better off. The real dispute, therefore, is over the definition of the best interests of the society, rather than whether the First Amendment should seek to augment either the public or the individual interest. ${ }^{24}$

The problem with the collective good approach to free speech, however, is not with the effort to justify and explain free speech as benefiting soci-

facts. In our problem, we must regard the desires and needs of the individual human being who wants to speak and those of the great group of human beings among whom he speaks. That is, in technical language, there are individual interests and social interests, which must be balanced against each other, if they conflict, in order to determine which interest shall be sacrificed under the circumstances and which shall be protected and become the foundation of a legal right. It must never be forgotten that the balancing cannot be properly done unless all the interests involved are adequately ascertained, and the great evil of all this talk about rights is that each side is so busy denying the other's claim to rights that it entirely overlooks the human desires and needs behind that claim.

Z. ChaFEe, FREE SPEECH IN THE UNITED STATES 31-32 (1941) (footnote omitted).

24. The central question asked in this essay is, "How do we benefit from tolerating speech?" The conventional response would be to say that the benefit comes in the form of receiving new, or additional, information and ideas. This is how Dworkin characterizes it in his critique of the public interest approach to free speech. See supra note 17. Dworkin proposes a speaker's rights analysis:

[A]ny conflict between free speech and the public's welfare is not a pseudo conflict between iwo aspects of the public's interest that may be dissolved in some judgment of its overall interest. It is a genuine conflict between the rights of a particular speaker as an individual and the competing interests of the community as a whole. Unless that competing interest is very great-unless publication threatens some emergency or other grave risk-the individual's right must outweigh the social interest, because that is what it means to suppose that he has this sort of right.

Dworkin, supra note 15, at 52. There are two principal problems with this analysis. The first is that it begs the questions of why the interest of the speaker should be accorded such a preeminent status. Only by labeling speech a "right," and then defining "rights" as taking precedence over competing social interests, is the result reached. The second problem concerns the assumption that a speaker's rights perspective, based on "principle," is desirable because it avoids the problem of thinking about how society will benefit by the protection of the speech. The court is advised to tally up the interests on each side, the community interest being defined generally as the harm that will arise from the speech, and the speaker's interest being the possession of an "equal voice," and then decide which is greater, holding its thumb on the free speech side of the scale. To conceive of First Amendment analysis in this way, however, is to limit unnecessarily one's vision of the role that the Amendment plays in society. To understand how society is better off by having a First Amendment does not mean, as Dworkin suggests, that the inquiry should be limited to an examination in the particular case of the practical benefits to be derived from the information offered by this speaker. To think in those limited, narrow terms is to restrict the meaning of an idea to its particular applications, and to limit the function of tolerating speech to that of preserving the flow of data. The benefits for the society in having an area of social life in which toleration is insisted upon, even to an extreme degree, can reasonably be thought to transcend the simple benefits of information. It is not uncommon in human behavior to run unusual levels of risk for other purposes beyond those involved in the discrete area in which the activity is undertaken.

The purpose of this Article is to begin to examine just what those broader societal benefits are thought to be. Understanding why speech is valuable to those engaged in it is an important inquiry, but understanding why people should be tolerant of those who seek those values is even more important; in fact, it is imperative for developing a viable First Amendment theory. The problem, therefore, is not whether reasons should be given but what reasons should be given-and, in that inquiry, we must not limit our perspective to "benefits" narrowly defined in terms of information flow. 
ety, but rather with its unnecessarily limited vision of what that larger benefit or social function is. For all the grandeur of its tone and language, the structural or public interest perspective of the First Amendment can offer a remarkably limited view of the role and function the concept plays in the general life of the society and in the minds of judges and others who enforce and write about it. It speaks usually in the language of pragmatism and rational thought; its focus purports to be on the flow and distribution of information, whether it be for truth-seeking generally or for political decisionmaking. Maximization of information and ideas for the society is said to be the primary aim.

The individual autonomy or speaker's rights perspective, which has so frequently objected to the limited purview of the instrumentalist perspective, has failed to generate accurate criticisms of that form of anlaysis. For example, the argument that the systemic perspective is inadequate because it does not protect speech that is socially but not necessarily politically significant, like literature and art generally, does not respond to the position of some purported systemic theorists that all such speech can be comfortably included within the domain of the politically relevant. Meiklejohn himself, when attacked for proposing a theory too narrow in compass, responded with just such a generous interpretation of his own arguments. ${ }^{28}$ Meiklejohn's answer has never seemed wholly satisfying for many people, but the reason it has proved unconvincing has nothing to do with its inherent improbability. In fact, it is entirely possible to conceive of a richly protective First Amendment that is exclusively tied to the process of democracy.

What is troublesome is the self-definition, the identity, implicit in the systemic theory itself. Free speech is not just a practical tool for making systemic repairs, but an affirmation or statement of what we value as a people. To define ourselves exclusively in terms of our political functions, however important they may be to us, is too limited a self-conception, even if all the forms of expression we value can be brought within the First Amendment sphere under the political speech designation. The reason we shelter speech is as important as the speech we shelter.

This tendency to ground criticism of the public interest perspective in claims about the scope of the free speech concept is symptomatic of a general inability or reluctance to take a larger view of the role played by the First Amendment in social life. An individualist perspective, which purports to remove from First Amendment analysis any consideration of the societal benefits derived from having such a constitutional concept, is quite unsatisfactory. What is needed is not an avoidance of consideration of the

25. See Meiklejohn, The First Amendment Is an Absolute, 1961 Sup. CT. Rev. 245, 263. 
societal role played by the idea of free speech but rather a redefinition, an enlargement, of the analysis of what that role is or purports to be. As presently conceived, however, the "self-government, public good" account of free speech is lacking in both explanatory and prescriptive power. It is but a patina, an epiphenomenon, beneath which deeper and more complex issues are being raised and addressed.

But what are those deeper and more complex issues? In this essay, I shall refer a great deal to what I shall call, for want of a better name, "intellectual values." I simply mean to inquire into how we are told to think about beliefs and ideas, and into the relationship we ought to strive for as we set about deciding questions of importance and dealing with conflicts within the society. The subject of this essay could just as well be put in terms of learning controls on the use of power, for the focus is on understanding not why speech is valued but why tolerance of it is demanded, a distinction in framing the inquiry into the social functions of the concept of free speech that I believe has important substantive connorations.

I will suggest that much of what we encounter in discourse about the First Amendment is really about fundamental intellectual values. Free speech is not just about getting more information and ideas needed to make good decisions, nor just about having the freedom to express ourselves as we see fit, but more importantly, and more broadly, about how to think, about such matters as our beliefs and about the fears and angers we bear towards the contrary beliefs and behavior of others. Refocusing our inquiry onto the question of how to think about information and ideas-an epistemological inquiry-will prove helpful in arriving at a general theory of the First Amendment. ${ }^{26}$

Our inquiry, in one sense, may be correctly described as intermediate. It avoids the dispute over whether the ultimate end of freedom of speech is a new vaccine, a better social security system, or a more fulfilled population. It focuses instead on the intellectual attributes people bring to the enterprise of truth-seeking, self-governance, or self-realization. It is also the case, however, that in this process we can see the glimmering of other ends and the beginnings of a foundation for a general theory.

The essay focuses briefly on the thought of two principal First Amendment theorists, Alexander Meiklejohn and Oliver Wendell Holmes. For several reasons the major emphasis is on Meiklejohn's theory. First, the intellectual values underlying Holmes' work on the First Amendment are much better known and much more congenial to our notions of what free

26. Much of the analysis that follows builds upon an earlier essay. See Bollinger, The Skokie Legacy: Reflections on an "Easy Case" and Free Speech Theory (Book Review), 80 MicH. L. REv. 617 (1982). 
speech means. Second, Meiklejohn seems to represent for us a more contemporary description or defense of the meaning of free speech and, thus, provides an image that is more currently significant. And, third, not only is Meiklejohn's work ultimately more novel and perhaps infused with greater contemporary significance, but it also is more revealing than that of other theorists.

In each case, however, the questions will be the same. What form of intellectual values is being recommended to those contemplating suppression of speech? What are the consequences to them in embracing those values? The problem is not to discern whether the theorist is arguing that freedom of speech seeks to protect the interest of each individual to speak, or the needs of self-government, or the search for truth, but instead to ask more generally about the intellectual outlook that is being advanced. The object is to locate the dispute between two major theorists and to speculate as to what consequences for a concept of free speech are generated by their competing visions. The general inquiry is presented as exemplary of the type of perspective that might be followed in thinking about freedom of speech. It also seeks to identify a major underlying conflict that resonates throughout the jurisprudence of the First Amendment. Indeed, the essay offers a hypothesis to account, at least partially, for why no general theory has emerged from this major set of writings.

Many elements of the perspective advocated in this essay will be presented as the argument is developed, but it may be useful to offer an introduction. First, it is desirable to move beyond the simple notion that the sole function of free speech is to protect "the people" from interference in their speech activities by the government. My point is not that there is no longer a risk that the government may seek to usurp free speech rights needed for self-government; the Pentagon Papers case ${ }^{27}$ suggests the contrary. Rather, I believe that this perspective is seriously incomplete. In contemporary America, restrictions on free speech are more frequently the product of democracy in action than officialdom seeking to regain prerogatives of the royal sovereign. It is necessary to escape the beguiling illusion that the battle against a despotic regime is still the exclusive war to be waged.

Next, it is important to avoid defining the value of the idea of free speech in terms of the activity of expression itself. It is still common to hear the explanation that speech activities of those wanting to be intolerant will be better secured if unpopular speech is protected. ${ }^{28}$ I do not claim that there is nothing to this type of argument. Rather, I claim that

27. New York Times Co. v. United States, 403 U.S. 713 (1971).

28. See infra note 46 . 
it is overused and that this overuse is suggestive of a general tendency to think about the function of free speech exclusively in terms of protecting our interest in preserving activity of speaking (or our interest in being free to listen to speech we wish to hear). When the argument for protection does turn to identifying other "benefits" for those seeking intolerance, the typical claim for free speech is that it guarantees the supply of information and ideas for decisionmaking. Such a perspective, however, is too narrow in two different ways. First, it offers an unfortunately quarantined vision of the benefits people may derive from tolerating that which they are disinclined to tolerate (perhaps even for good reason). It tends to view those benefits narrowly in terms of practical gains, rather than in terms of remedying some inherent and fundamental problem that happens to reveal itself in the context of intolerance towards speech activities. Second, it is part of an attempt to isolate the benefits of free speech to those that arise from the act of speaking or of expression (in contrast, say, to those that might arise from nonexpressive behavior), rather than to envision its aim as that of addressing a problem or issue of universal importance in human affairs by advancing remedies of equally wide significance.

With these general changes in perspective in mind, the analyses of free speech by Meiklejohn and Holmes can be considered.

I.

Meiklejohn's essay is a curious and deceptive work. While the line of argument seems simple to follow, the reader often feels that something-some other argument or set of arguments-is being missed. The essay is even more puzzling to view as a "great" piece of First Amendment writing because so much of it crumbles on slightest handling, leading one to believe that it cannot be logic that accounts for its success. The message and power of the essay are elusive.

A conventional reading of Meiklejohn would cite him for advancing the fundamental proposition that, in a society that has chosen to be self-governing, the government cannot label some information as too dangerous or wrong for that society to hear. To permit such censorship is to negate the original premise of self-government, because to be self-governing a citizenry must have the information and ideas necessary for decisionmaking. Hence, Meiklejohn is noted for arguing that the meaning of free speech must be that all speech relating to the process of self-governance is "absolutely" protected against governmental suppression.

Two other corollaries to Meiklejohn's major thesis are well known and commonly mentioned. The first is the claim that the First Amendment protects only speech relevant to the process of self-government, the remainder being relegated to the reduced protections of the due process 
clause of the Fifth Amendment. ${ }^{29}$ His working concepts for these different categories of speech are what he called "public" and "private" speech. Public speech is that used by people to plan together for the general welfare. Private speech has a more selfish motivation behind it and is not directed at solving public issues: "There are, then, in the theory of the Constitution, two radically different kinds of utterances. The constitutional status of a merchant advertising his wares, of a paid lobbyist fighting for the advantage of his client, is utterly different from that of a citizen who is planning for the general welfare."30

A second major corollary to Meikeljohn's thesis concerns the scope of permissible regulations within the category of public speech. While such speech cannot be prohibited on the ground that it is "dangerous," it is not on the other hand entirely free from any restriction whatever. Meiklejohn claimed to take the practical view. His central image is the New England town meeting, at which people "assembled, not primarily to talk, but primarily by means of talking to get business done." Rules of procedure are therefore necessary and under them a speaker could be declared "out of order," to which it would be no valid response to assert a right to "talk as he pleases, when he pleases, about what he pleases, about whom he pleases, to whom he pleases." would impose in the context of public decisionmaking arise from the general principle that "the point of ultimate interest is not the words of the speakers, but the minds of the hearers." Or, expressed in another form that has been frequently quoted: "What is essential is not that everyone shall speak, but that everything worth saying shall be said." 32 The principle of free speech in this sense serves a "public" and not a "private" interest.

These general elements of a theory of free speech seem quite insufficient to justify treating the essay as a major work. The basic idea, that a democracy requires freedom of expression among the citizens, is, if not obvious, then hardly original with Meiklejohn. One can find in the literature prior to Meiklejohn many similar justifications for the principle of free speech..$^{33}$ As to the corollaries, the first, that free speech protects only

29. As noted earlier, see supra p. 444 , Meiklejohn subsequently gave this apparently severe limitation on the scope of the First Amendment an expansive interpretation; nevertheless, Meiklejohn did in theory keep all protected speech umbilically tied to the concept of self-government.

30. A. MEIKLEJOHN, supra note 8 , at 37 . The recently enunciated commercial speech doctrine rejects Meiklejohn's relegation of commerical speech to Fifth Amendment protections. See Virginia State Bd. of Pharmacy v. Virginia Citizens Consumer Council, Inc., 425 U.S. 748 (1976); Bigelow v. Virginia, 421 U.S. 809 (1975).

31. A. MEIKLEJOHN, supra note 8 , at $24-25$.

32. Id. at 26 .

33. Chafee himself observed that one of the two interests protected by the First Amendment, besides the "individual interest, the need of many men to express their opinions on matters vital to 
public speech, has never really caught much attention, and for good reason. ${ }^{34}$ The other, that free speech must be interpreted according to what best serves the "collective" or "public" interest, again was hardly new with Meiklejohn. That he was prepared to make this the only interest advanced by the First Amendment may be of interest, but only marginally so. On the score of originality, in sum, it would seem that Meiklejohn's fame is quite undeserved.

On the level of rational argumentation, the essay is at best unsophisticated. This is especially true of a series of arguments from the constitutional text that Meiklejohn uses to support his theses. Meiklejohn argues, for example, that no public speech, however dangerous, can be excluded from public debate. He supports this position in part by making an exegetical foray into the language of the Constitution. First, he notes that Article I, section 6-the speech and debate clause-provides "uncompromising" and "absolute" protection to the speech of our political representatives. ${ }^{35}$ Second, he posits that under the theory of democracy, all rights and powers of the representatives are merely "derivative" of the citizens. From the two assertions, he concludes a fortiori that the same degree of protection for speech accorded to representatives must also be accorded to citizens. ${ }^{36}$

The argument is deficient on at least two grounds. First, it assumes away the problem by proceeding on a debatable interpretation of Article I,

them if life is to be worth living," was the "social interest in the attainment of truth, so that the country may not only adopt the wisest course of action but carry it out in the wisest way." $Z$. CHAFEE, supra note 23, at 33. Brandeis said it more explicitly in his concurrence in Whitney: "Those who won our independence believed that . . . freedom to think as you will and to speak as you think are means indispensable to the discovery and spread of political truth; that without free speech and assembly discussion would be futile." Whitney v. California, 274 U.S. 357, 375 (1927) (Brandeis, J., concurring).

34. See supra pp. $447-48$.

35. Article I, section 6 of the Constitution states in relevant part that "for any Speech or Debate in either House, [Senators and Representatives] shall not be questioned in any other Place." U.S. CONST. art. I, § 6.

36. See A. MEIKLEJOHN, supra note 8, at 36. It appears that precisely this argument was made at the beginning of the nineteenth century. Professor Levy describes a new argument for free speech made by John Thomson in 1801:

He noted that Article One, Section Six, of the Constitution provided that members of Congress "shall not be questioned," that is, held legally liable, for any speech they might make; their remarks were clothed with an immunity that gave them the right to say whatever they pleased in their legislative capacities. Thomson then reasoned that if freedom of discussion was necessary for them, it was equally necessary, indeed more so, for their sovereigns, the people whom they represented. The electorate must pass judgment on the proceedings of Congress and insure that the government operated for the benefit of the government [sic]. For the fulfillment of their electoral duties and their responsibility to protect themselves, the people could not be denied access to any viewpoint. The agents of the people were accordingly powerless to abridge the freedom of speech or press. The intention of the framers of the First Amendment, Thomson concluded, was to guarantee that the people possessed "the same right of free discussion" as their agents.

L. LEVY, THE LEGACY OF SUPPRESSION: FREEDOM OF SPEECH AND PRESS IN EARLY AMERICAN HISTORY 296 (1963) (citing J. THOMSON, AN ENQUIRY, CONCERNING THE LIBERTY, AND LICENTIOUSNESS OF THE PRESS, AND THE UNCONTROULABLE NATURE OF THE HUMAN MiND 20, 22 (1801)). 
section 6 . But more to the point and more problematic is the unexamined assumption of a perfect equivalence between the speech protected under that clause and speech protected under the First Amendment. It would hardly seem self-evident that the framers believed that the scope of protected debate on the floor of the Congress would be precisely coextensive with that throughout the country at large; indeed one interpretive stance would be to draw precisely the opposite conclusion from the different language employed in each section of the document. And, even apart from what the framers intended, a good case could be made for not regarding both provisions as coextensive. The nature of the process of selection for those who will operate within the legislative arena and the types of people who are likely to inhabit the congressional halls might lead one to tolerate much greater freedom of discussion there than among the general population, where indirect controls over irresponsible speech are far less extensive. Only by ignoring the possibility of different degrees of concern about legislative and public debate could Meiklejohn so facilely reach the conclusion that the First Amendment protects, for example, subversive speech because it is coextensive with the speech and debate clause.

Nor would a view opposed to Meiklejohn necessarily negate the choice to be "self-governing," since people continue to retain the right to elect their representatives and to vote on issues of their choice. The problem is one of determining the degree to which, under the Constitution, the general society is to govern itself, or, to put the matter slightly differently, of just how the process of self-government should be structured. In sum, the difficulty is in defining and justifying what we mean by self-government and why self-government excludes restrictions on political speech, a problem that Meiklejohn assumes away by this textual legerdemain. ${ }^{37}$

37. Meiklejohn also drew textual sustenance for his thesis from the wording of the due process clause of the Fifth Amendment. U.S. CONST. amend. V (No person shall . . . be deprived of life, liberty, or property, without due process of law . . . .). He reasoned as follows: (i) The language of the First Amendment with respect to freedom of speech is an absolute prohibition against official or governmental abridgement. U.S. CONST. amend. I (Congress shall make no law ... abridging the freedom of speech . . . . .). (ii) The Fifth Amendment permits the abridgement of liberty as long as it is accomplished in a manner consistent with due process. (iii) The term liberty in the due process clause includes speech. (iv) Since, therefore, the First Amendment forbids completely the abridgement of freedom of speech, while the Fifth Amendment due process clause permits the abridgement of speech, then one can conclude that the framers intended to divide speech into two classes. Those classes are the "freedom of speech"-public speech of the "citizen who is planning for the general welfare"-and the "liberty of speech"- the private speech of, for example, the "merchant advertising his wares, of a paid lobbyist fighting for the advantage of his client." A. MEIKLEJOHN, supra note 8, at 34-37.

A final textual argument is Meiklejohn's claim that the language of the First Amendment is itself absolute with regard to the speech it protects. That speech, as we have seen, was to Meiklejohn the public speech of planning for the general welfare. For a moment Meiklejohn considers whether the clause of the First Amendment providing for the right to petition for redress of grievances indicates an intent to protect a mere private interest, thereby reflecting a similar intent on the freedom of speech clause. Meiklejohn, however, happily concludes that his interpretation is not thwarted since "such a 
Doubts about the magnitude of Meiklejohn's achievement, however, go far beyond questions about his originality and skill at standard legal analysis. They go to the fundamental issue of whether what he has to say, or has been interpreted as saying, has any real meaning for the world that we inhabit. Confronting the two fundamental issues involved here will move us onto another level of the essay's meaning.

The first issue is against whom or what does the First Amendment provide protection. Meiklejohn's essay would hardly be memorable if it were limited to the claim that the purpose of free speech is to keep the "government" from interfering with the exercise of self-government by the citizens. This would be a gross distortion of the reality of intolerance toward speech, which arises not simply, or even primarily, from unauthorized official censorship but from democracy at work, from a majority demanding or wanting their government to prohibit certain forms of expression from public discourse. To see this reality, however, is to pose a major conundrum for free speech theory, especially a theory that justifies free speech in terms of its contribution to the democratic system. For it appears anomalous to restrict limitations on speech in the name of preserving self-government when the self-governing process has generated

petition, whatever its motivation, raises definitely a question of public policy. It asserts an error in public decision . . . . They ask, therefore, for reconsideration. And in doing so, they are clearly within the field of public interest." Id. at 38.

These two other arguments similarly fail to lend a degree of textual inevitability to Meiklejohn's claim for tolerance. He mistakenly assumes that the First Amendment necessarily takes a category of speech, like political or public speech, and protects it absolutely. It certainly is true that the language of the First Amendment means that whatever is protected is protected, but beyond this tautological statement, nothing certain can be gleaned. While Meiklejohn does not commit the sophomoric error of claiming that the wording of the First Amendment is absolute in the sense of protecting all speech (it only protects against abridgement of the freedom of speech), he does make a partial error in that direction by simply asserting without argument that the category of public speech is protected by the First Amendment.

Meiklejohn next commits an error in reading the Fifth Amendment. Once he concludes that the due process clause was intended to protect speech, he then jumps to the conclusion that the intent was to create or divide speech or discussion into two categories, by their subject matter and context. As noted above, it is not at all clear that the term "freedom of speech" in the First Amendment means only (or even principally) public speech. Nor is that conclusion automatically reached by a negative inference drawn from an interpretation of the Fifth Amendment as limited to private speech or discussion. Meiklejohn leaps to the conclusion that because the Fifth Amendment also includes speech within its protections, it must be a different category of speech than the category within the First Amendment. But this need not be the case. It might just as easily be read as establishing only that the First Amendment protects certain speech against abridgement and that speech not protected there is nevertheless subject to the Fifth Amendment protections of due process.

Meiklejohn's argument with respect to the wording of the First and Fifth Amendments is really directed at his claim that there is a public-private distinction drawn there. But it does not follow that any particular speech, and especially subversive speech, must fall within the public discussion category. Thus, even if one grants Meiklejohn all of his inferences as to the categories protected by the First and Fifth Amendments, there is still the critical question why particular speech should be protected as within the public speech category.

Meiklejohn therefore is really making two distinct arguments that he never fully separates: One has to do with the categories of speech protected and not protected, and the other has to do with the definitions of those categories. 
those very limitations.

Meiklejohn, of course, was conscious of this more complex facet of democracy. He was writing in the immediate postwar years, at the beginning of the Cold War. This period bore a close parallel to the intolerant climate during and immediately after the First World War, when Holmes first dealt with the subject of free speech. In his preface, Meiklejohn spoke to this reality of intolerance, noting how an extensive system of internal security had been devised, with widespread public support to uncover "un-American" and "disloyal" activities and agents. Referring to Federal Bureau of Investigation activities, Meiklejohn said:

And that procedure reveals an attitude toward freedom of speech which is widely held in the United States. Many of us are now convinced that, under the Constitution, the government is justified in bringing pressure to bear against the holding or expressing of beliefs which are labeled dangerous. Congress, we think, may rightly abridge the freedom of such beliefs. ${ }^{\text {s8 }}$

These were "wretched days of postwar and, it may be, of prewar, hysterical brutality."39 The question to be answered, then, was should the society refrain from employing legal coercion against these subversive ideas, against those who would say that "the Constitution is a bad document," "that war is not justified," "that conscription . . . is immoral and unnecessary," "that the [political systems] of England or Russia or Germany are superior to ours." ${ }^{\circ 0}$ Even more pointedly, he asks, "[S]hall we listen to ideas which . . . might destroy confidence in our form of government," from those who "hate and despise freedom, to those who, if they had the power, would destroy our institutions."41 Should we permit the publication of Hitler's Mein Kampf, of Lenin's The State and the Revolution, or of Engels' and Marx's Communist Manifesto? ${ }^{\mathbf{2}}$

But it is precisely the move to this more specific reality that gives rise to the second apparent anomaly confronting Meiklejohn's thesis. The prob-

38. A. MEIKLEJOHN, supra note 8 , at 4 . Chafee noted the same disturbing trends:

This is a timely book. The country seems to be suffering again from an epidemic of hysteria such as it underwent during the "Red Menace" of 1919-1920. Even men who recognize "that the dangers from subversive organizations at the time of World War I were much exaggerated" are so apprehensive of the dangers from subversive organizations today that they are once more seeking to fight objectionable ideas with long prison sentences and heavy pecuniary penalties. If the First Amendment as construed by the Supreme Court prevents such suppression, then they propose to amend the First Amendment in order, so they say, "to preserve the whole Constitution."

Chafee, Book Review, 62 HARV. L. REV. 891, 892 (1949).

39. A. MEIKLEJOHN, supra note 8 , at 43.

40. Id. at 27-28.

41. Id. at 57 .

42. See id. at 77 . 
lem is not just in answering the general question, "What do you do when the public has restricted speech through the democratic process?" but in answering the further question, "Why protect this particular brand of speech?" At the time Meiklejohn wrote, not only was there a form of selfgovernment actually at work, though perhaps not the one Meiklejohn would have wanted, but the type of speech being excluded from the system was that which allegedly directly challenged, or sought to undermine, the system itself. Why should a theory of free speech, which envisions its purpose as serving the system of self-government, lead to the conclusion that a self-governing society cannot choose to prohibit speech which advocates the end of self-government itself?t3

A.

To put Meiklejohn's argument in broader context, it is helpful to pause and consider what paths might be seen as open for a defense of free speech. ${ }^{44}$ One path is to claim the role of protecting the rights of minorities within the political system, to assert their interests against a tyrannical, however momentary, majority. Such an argument saves one from the conundrum of serving democracy while defeating it, but only at serious cost. As a practical matter, one might wonder how long a "right" that is not defended as having any general societal purpose or value, apart from serving the interests of a few members of the society, can survive. Such a claim shatters any relationship other than that of brute power between the legal system, the courts, and the larger society. This argument becomes even more difficult to advance as the speech becomes more extremist in character. And it is also shortsighted, for the thinking that motivated the act of intolerance in this instance will most surely motivate other undesirable behavior in areas beyond the reach of the First Amendment, and probably defeat whatever gains have been temporarily achieved by virtue of the application of the First Amendment here.

43. Professor Bork concludes that under a theory of free speech that draws its importance from the system of self-government, such speech cannot be protected:

Speech advocating forcible overthrow of the government contemplates a group less than a majority seizing control of the monopoly power of the state when it cannot gain its ends through speech and political activity. Speech advocating violent overthrow is thus not "political speech" as that term must be defined by a Madisonian system of government. It is not political speech because it violates constitutional truths about processes and because it is not aimed at a new definition of political truth by a legislative majority. Violent overthrow of government breaks the premises of our system concerning the ways in which truth is defined, and yet those premises are the only reasons for protecting political speech. It follows that there is no constitutional reason to protect speech advocating forcible overthrow.

Bork, supra note 10, at 31 . Wigmore argued similarly in 1920 . See Wigmore, Abrams v. U.S.: Freedom of Speech and Freedom of Thuggery in War-Time and Peace-Time, 14 ILL. L. REV. 539, 55657 (1920).

44. See Bollinger, supra note 26. 
An intermediate course is to claim for the free speech idea only the role of an umpire who insures that every idea has a fair opportunity to become a majority position. Under this argument, the principle of free speech might be thought about with a more expanded temporal perspective: While the present majority may have expressed its will in prohibiting this speech, it cannot so alter the system as in effect to bind the future democracy, which might find the censored ideas more to its liking. This seems to be what Alexander Bickel had in mind when he said that "[t]he social interest that the First Amendment vindicates is . . . the interest in the successful operation of the political process, so that the country may better be able to adopt the course of action that conforms to the wishes of the greatest number, whether or not it is wise or is founded in truth." ${ }^{245}$ While momentarily attractive, such a perspective does not withstand scrutiny. An umpire issues judgments on rules made by others; the courts in the free speech setting make the rules as they go along, and that is the source of the problem. What speech is needed or relevant to the "process" and why it is needed would still be unanswered questions.

A third route defends the enforcement of the free speech principle in the face of a democratically arrived-at decision to the contrary as a preferable choice for the society itself and the majority. The focus is not on the protection of minorities against overreaching majorities, nor on the umpire's limited interference for the purpose of insuring a continuous opportunity for the formation of true majorities, but rather on a redefinition for the majority of its own best interests. The concern is with the society at large, of which the majority itself is a part.

A series of arguments, several of which may be called arguments of expediency, cohere around this third approach. It is commonly said, for example, that we are better off with protection because of the risks involved in drawing lines-the perennial claim of the slippery slope. ${ }^{46}$ Or it can be emphasized that we are all potential minorities. Or a safety valve argument may be raised, claiming that we are better off by letting the dissidents blow off steam vocally than through covert subversive activities. ${ }^{47}$ Or it can be said that we need not worry or bother because truth

45. A. BICKEL, supra note 11 , at 62 .

46. This is one of the more common varieties of First Amendment claims, vying for honors with the related "chilling effect" argument as the most frequently used. It played an important role in the most recent major "extremist speech" case, Village of Skokie v. National Socialist Party of Am., 69 Ill. 2 d 605,373 N.E.2d 21 (1978). I have commented on the argument in two contexts, one regarding the Skokie cases and the other broadcast regulation. See Bollinger, supra note 26, at 623-24, 626-28; Bollinger, Freedom of the Press and Public Access: Toward a Theory of Partial Regulation of the Mass Media, 75 MICH. L. REV. 1, 31-32 (1976).

47. As Justice Brandeis wrote:

But they knew that order cannot be secured merely through fear of punishment for its infraction; that it is hazardous to discourage thought, hope and imagination; that fear breeds repres- 
will win in the end. ${ }^{48}$ Finally, and more relevant to the present discussion, we have the claim that we benefit from the act of listening to or tolerating these people, hearing rather than suppressing the speech.

Within this last mentioned category of arguments we find principals like John Stuart Mill, Holmes, and Meiklejohn. Mill, of course, argued that it was in the interest of the majority to avoid suppression because the ideas suppressed might be true, or, if not true, then sufficiently stimulating in their confrontation with the majority's beliefs to make toleration worthwhile, if not mandatory. ${ }^{4}$

Quite clearly, Meiklejohn falls within the third approach; to him the only legitimate function of free speech was the advancement of the public, or collective, interest, not the realization of any private needs. But what exactly is this collective interest served by the protection of speech? What would the society gain by following such a course of action? It is either inaccurate or too simple to suggest that Meiklejohn, like Mill, believed the advantage would be a new truth or a more lively sense of existing truth. And, despite his frequent claim that his was a practical, business-like orientation to the First Amendment, Meiklejohn never really said what important information would be the payoff for the act of tolerance. Plausible arguments might, of course, be imagined. It might be thought useful to know what everyone is thinking within the society, especially those segments that are most likely to act destructively. Such data could conceivably be helpful in organizing the society, distributing benefits, or identifying and correcting problems. Or, a more limited argument might be that the society has, through the act of suppression, effectively rendered itself incapable of engaging in self-government since it no longer has the minimally necessary information to make intelligent decisions. ${ }^{80}$

sion; that repression breeds hate; that hate menaces stable government; that the path of safety lies in the opportunity to discuss freely supposed grievances and proposed remedies; and that the fitting remedy for evil counsels is good ones.

Whitney v. California, 274 U.S. 357, 375 (1927) (Brandeis, J., concurring).

48. The foremost expression of this view is in Milton's Areopagitica:

[T]hough all the windes of doctrin were let loose to play upon the earth, so Truth be in the field, we do injuriously by licensing and prohibiting to misdoubt her strength. Let her and Falshood grapple; who ever knew Truth put to the wors in a free and open encounter? Her confuting is the best and surest suppressing.

J. MiLTON, AREOPAGITICA 51-52 (J. Hales ed. 1961). Bickel said: "[W]e have lived through too much to believe it." A. BICKEL, supra note 11 , at 71 .

49. J. MILL, ON LIBERTY 21 (C. Shields ed. 1956).

50. This argument is analogous to Mill's argument for prohibiting voluntary slavery. See id. at 125. If the state does not interfere with an individual's freedom to enslave himself, the individual may use his valuable freedom to alienate that same freedom. Similarly, if the government is not restrained in acting to prohibit speech, it alienates its ability to govern informedly. A similar argument has been employed to justify extending First Amendment rights, especially to the press, under a self-government theory of the First Amendment. Professor Dworkin discusses and rejects Justice Brennan's use of such an argument in Richmond Newspapers.

The second argument, stressed particularly in Brennan's opinion ... urges that some spe- 
But Meiklejohn never offered such arguments. ${ }^{51}$ Despite his early comments on the function of free speech in getting the society's business done, the progression of the essay is away from the pragmatic aspects of the third approach until, by the next to the last chapter, he is speaking broadly of basic intellectual values that are symbolized in the act of tolerance he sought. Here we find the essay's power: not in its logic, but in the manner in which it characterizes the acts of tolerance and intolerance and the images it evokes for each.

In Meiklejohn's terms, the act of toleration, especially of extremist views, becomes a means by which the society communicates and affirms its own principles. That these principles are contrary to those of the speaker does not take away from the possibility of communication and affirmation; this conflict instead creates the opportunity and actually enhances it. Tolerance in this way demonstrates, or proclaims, confidence in and commitment to belief. It also bespeaks control, symbolized by the very theory of free speech itself under which the right is tied to its usefulness to the general society. Meiklejohn speaks in the language of "the citizens," "the community," "the compact," "the general welfare," "the common good," and "fearlessness." 62 That people are not the way he would like is openly acknowledged and partially forgiven, for it is also recognized that to master self-governance as Meiklejohn would have it is most difficult. The way is nevertheless clear, and it is the role of the Court to lead us there.

Meiklejohn believed in and advocated the possibility of complete selfgovernance, of self-determination, whether for an individual or a group. With groups, the state of self-governance was initiated by agreement or

\footnotetext{
cial protection for the press is necessary in order not simply to advance the general good but to preserve the very structure of democracy. Madison's classic statement of this argument is often cited in the briefs the press submits in constitutional cases. He said that "a popular government, without popular information or the means of acquiring it, is but a prologue to a farce or a tragedy; or perhaps both .... a people who mean to be their own governors, must arm themselves with the power knowledge gives."

... But the Madisonian argument from the structure of democracy cannot be open-ended, for then it will end in paradox and self-contradiction.

That is so because every extension of the First Amendment is, from the standpoint of democracy, a double-edged sword. It enhances democracy because public information increases the general power of the public. But it also contracts democracy because any constitutional right disables the popularly elected legislature from enacting some legislation it might otherwise wish to enact, and this decreases the general power of the public ....

Dworkin, supra, note 15 , at 53-54.

51. Meiklejohn did speak in highly general terms about the advantages of full information: Now, in [a town meeting] method of political self-government, the point of ultimate interest is not the words of the speakers, but the minds of the hearers. The final aim of the meeting is the voting of wise decisions. The voters, therefore, must be made as wise as possible. The welfare of the community requires that those who decide issues shall understand them. They must know what they are voting about. And this, in turn, requires that so far as time allows, all facts and interests relevant to the problem shall be fully and fairly presented to the meeting.

A. MEIKLEJOHN, supra note 8 , at 26.

52. See id. at $14,17-19,42,73-75$.
} 
contract, such as those most commonly associated with the country's heritage (the Mayflower Compact, the Declaration of Independence, the Constitution). ${ }^{53}$ But, for Meiklejohn, the idea of self-government had a special

\section{See id. at 17-18.}

It was on the basis of an interpretation of Meiklejohn as arguing for the political and sovereign right of democratic citizens to receive all information relevant to political issues that Professor Scanlon constructed his broader theory of freedom of speech as constituting the protection of "individual autonomy." See Scanlon, supra note 19. Basing his theory on what he called the "Millian Principle," Scanlon argued that certain "harms" could not "be taken as part of a justification for legal restrictions" on acts of expression:

These harms are: (a) harms to certain individuals which consist in their coming to have false beliefs as a result of those acts of expression; (b) harmful consequences of acts performed as a result of those acts of expression, where the connection between the acts of expression and the subsequent harmful act consists merely in the fact that the acts of expression led the agents to believe (or increased their tendency to believe) these acts to be worth performing.

Id. at 213. He subsequently described his objectives in the following terms:

I undertook to defend this principle by showing it to be a consequence of a particular idea about the limits of legitimate political authority: namely that the legitimate powers of government are limited to those that can be defended on grounds compatible with the autonomy of its citizens-compatible, that is, with the idea that each citizen is sovereign in deciding what to believe and in weighing reasons for action. This can be seen as a generalized version of Meiklejohn's idea of the political responsibility of democratic citizens.

Scanlon, Freedom of Expression and Categories of Expression, 40 U. PITT. L. REV. 519, 531 (1979). On reflection, however, he later felt compelled to abandon the theory as incorrect. Of primary concern to him was the realization, or recognition, that the pursuit of being "autonomous," at least in the sense of acquiring all relevant information needed for independent decisionmaking, or self-government, was not an exclusive, or in some instances even a primary, end of human life:

Additional information is sometimes not worth the cost of getting it. The Millian Principle allows some of the costs of free expression to be weighed against its benefits, but holds that two important classes of costs must be ignored. Why should we be willing to bear unlimited costs to allow expression to flourish....?

Id. at 533.

Professor Scanlon continues to believe that fundamental human interests are at stake both in the act of expression and in having access to expression (audience interests) and argues in favor of a generally strong level of protection for certain "categories" of expression, especially "political" expression, on the ground that "where political issues are involved governments are notoriously partisan and unreliable. Therefore, giving government the authority to make policy by balancing interests in such cases presents a serious threat to particularly important participant and audience interests." Id. at 544 .

I do not wish here to engage in a lengthy discussion of this line of theory about free speech, but Scanlon's arguments are importantly instructive in a number of respects. I agree with Scanlon's insightful self-criticism. A central problem with theories about the "values" we derive from being free to speak and to listen to speech we like is that they tend to be overstated in terms of actual life experience. To say that with free speech we are seeking to implement our desire for total "autonomy" as sovereign individuals is to exhibit a unidimensional perspective or singlemindedness about the ends of life that is unrealistic. As Scanlon realized, life experience demonstrates that we regularly take other competing interests into account in situations in which access to information is at issue. Furthermore, the sense that our "autonomy" is being infringed upon by a given restriction on access to information is importantly affected by the process by which that restriction is adopted. The notion of an alien "government" or "state" passing the restrictions helps create a sense of invasion; thinking in terms of a true "democratic" decision lessens that feeling.

On the other hand, it is possible to see in the protection of speech not simply the pursuit of some universal and exclusive value-like "autonomy" of decisionmaking-but also the attempt to identify and correct some perceived defect in our attitudes. One must still make the claim that this is something one ought to or does want corrected, but one does avoid the problem of having to demonstrate that human behavior consistently adheres to a single end or interest. Furthermore, the discussion in the text attempts to show that Meiklejohn did not rest his argument for free speech on the ground of a universal interest in being "self-governing" but rather in a perceived lack of interest in being in that position, seeing in that perceived deficiency a general way of thinking he found unsatisfactory. 
meaning, a value that was independent of the particular governmental choices or decisions arrived at. To exist under the power of a perfectly governed regime would mean losing the satisfactions, the dignity, of being capable of self-control.

To be self-governing, as Meiklejohn would have it, however, could not include all possible outcomes of self-government. An individual or society could not claim to be self-governing if it decided, even unanimously, not to consider or hear a particular idea, and especially not if the reason behind the exclusion or suppression was that the idea was determined to be hateful, frightening, or wrong. The child who "decides" to flee an imagined ghost does not possess self-control. Control comes only with the mastery of such fears, and that is why Meiklejohn could say that "[t]o be afraid of ideas, any idea, is to be unfit for self-government." ${ }^{254}$ The essence of selfgovernance is the willingness to confront every idea, everything that is being said; it is the absence of censorship. Meiklejohn acknowledged that people are very much inclined to take the opposite direction; we would all just as soon not be self-governing in this sense. ${ }^{55}$

And so, the problem was not one simply of keeping a constantly encroaching government from stealing back political power from a weaker or perhaps unsuspecting populace, but of stopping the people themselves from giving up a role, or a capacity, from which their natural tendencies make them want to stray. The problem was not simply seditious libel, but the far more difficult challenge of creating the democratic personality. The role of the courts, and especially of the Supreme Court, in this ongoing process was that of the educator, or teacher. Meiklejohn described the purpose of his own lectures as that of educating the public about the "basic plan" of American government. But, to him, the Supreme Court was our foremost "teacher" on that subject: "The Supreme Court, we have said, is and must be one of our most effective teachers. It is, in the last resort, an accredited interpreter to us of our own intentions."

Meiklejohn's argument, therefore, assumes an equivalence between the state of being self-governed and the absence of censorship. The end sought was not merely wise decisions, but a personal capacity achieved through the search for those decisions. The language employed gives hints of this deeper value. To exclude some speech or ideas from public discourse is to be "fearful," "insecure," "ignorant," "unfit for self-government," to "flinch." But to tolerate them is to "face up to ideas," to be "fearless,"

54. A. MEIKLEJOHN, supra note 8 , at 28.

55. Id. at 10.

56. Id. at 51. A question of obvious significance that I do not address in this Article is that of the legitimacy or capacity of the judiciary to articulate intellectual values, which as I suggest, Meiklejohn, Holmes, and others were in fact doing. 
"unflinching," and otherwise "self-reliant."

Meiklejohn went further, however. Within this specially defined capacity of self-government, he insisted upon a broadly conceived system of intellectual values. Self-governance was not just facing up to every idea, however wrong or dangerous it might be regarded, to be followed by a single count of noses. In particular, it was emphatically not a matter of each citizen merely figuring out what was "good for him" and then voting on that basis. For Meiklejohn, true self-government was conducted according to an intellectual standard by which every citizen thinks and votes in terms beyond himself, objectively, and in pursuit of the general, collective welfare. ${ }^{88}$ To Meiklejohn, beliefs could be assessed as good or bad, true or false, and part of the capacity we seek is to be better able to render judgments about them. Some beliefs were true, and one of the functions of the First Amendment was to make possible the communication of truths by those who had it to those who did not. ${ }^{59}$ Meiklejohn himself gave the impression of a man who believed he possessed the truth about the right kind of community values.

Thus, with Meiklejohn, the First Amendment embodies an intellectual life in the broadest sense, one to which we aspire under the tutelege of the Supreme Court. The First Amendment recommends to us a set of intellectual values that speaks to the unsatisfying and dwarfing character of censorship, that identifies what is relevant for political decisionmaking and that explains how we should think about what is relevant. Here, then, are the answers to the double paradox. There is no contradiction in overturning censorship arrived at by majority (or even unanimous) vote, for that is not and cannot be true self-government; it is not what we ought to mean by self-government. Self-government in this sense means not only the absence of censorship but also a set of attitudes about how each member of

57. Meiklejohn spoke repeatedly of the need for protection of radical speech, and whenever he did so his argument shifted from the need for information to the possibility of fearlessness:

If, then, on any occasion in the United States it is allowable to say that the Constitution is a good document it is equally allowable, in that situation, to say that the Constitution is a bad document. If a public building may be used in which to say, in time of war, that the war is justified, then the same building may be used in which to say that it is not justified . . . . These conflicting views may be expressed, must be expressed, not because they are valid, but because they are relevant. If they are responsibly entertained by anyone, we, the voters, need to hear them. When a question of policy is "before the house," free men choose to meet it not with their eyes shut, but with their eyes open. To be afraid of ideas, any idea, is to be unfit for self-government.

Id. at 27-28 (emphasis added).

Praising Brandeis' remarks in Whitney, Meiklejohn adds, "We Americans are not afraid of ideas, of any idea, if only we can have a fair chance to think about it." Id. at 48; see also id. at 77 ("We are saying that the citizens of the United States will be fit to govern themselves under their own institutions only if they have faced squarely and fearlessly everything that can be said in favor of these institutions, everything that can be said against them.").

58. Id. at 73-75.

59. Id. at 74-75. 
the community should relate to every other member.

The other portion of the paradox concerns the extent of the principle of self-government: why it makes sense to insist upon tolerance for those who would advocate destruction of the system itself, however defined. Under Meiklejohn's argument, the anomaly is only apparent. One can envision at least two functions served by tolerance in such a case, both of which can be seen as implicit in the general argument. The first relates to the pedagogical role the Court assumes under the aegis of free speech. The instructional advantages of extremes are, of course, well known and no doubt did not escape the intuitive attention of an educator like Meiklejohn. The drama and tension of aberrant behavior has, at a minimum, an attention-commanding capacity, which somewhat ironically means that the system can beat the radicals at their own game. But there is a deeper, more substantive gain from tolerance.

For it is extremeness itself, and the very fears evoked by it, that make tolerance of free speech mandatory under a regime like Meiklejohn's. To a society that seeks to develop a certain capacity, especially one of security and control, toleration can help to establish or prove symbolically the arrival of that capacity. Often, the harder something is to do the more symbolic meaning the doing of it carries. For speech that attacks and challenges community values, the act of toleration serves both to define and reaffirm those values; the act of tolerance implies a contrary belief, and demonstrates a confidence and security in the correctness of the community norm. Through toleration, in short, we create the community, define the values of that community and affirm a commitment to and confidence in those values. To think of freedom of speech in this way evokes Seneca's prescription on mercy-its primary value, when implemented by the ruler, is in what it bespeaks of the party who is merciful, his confidence and security and self-restraint in the face of challenges to that authority. ${ }^{60}$

\section{Seneca wrote:}

Every house that mercy enters she will render peaceful and happy, but in the palace she is more wonderful, in that she is rarer. For what is more remarkable than that he whose anger nothing can withstand, to whose sentence, too heavy though it be, even the victims bow the head, whom, if he is very greatly incensed, no one will venture to gainsay, nay, even to entreat-that this man should lay a restraining hand upon himself, and use his power to better and more peaceful ends when he reflects, "Any one can violate the law to kill, none but I, to save"? A lofty spirit befits a lofty station, and if it does not rise to the level of its station and even stand above it, the other, too, is dragged downward to the ground. Moreover, the peculiar marks of a lofty spirit are mildness and composure, and the lofty disregard of injustice and wrongs. . . Cruel and inexorable anger is not seemly for a king, for thus he does not rise much above the other man, toward whose own level he descends by being angry at him. But if he grants life, if he grants position to those who have imperilled and deserve to lose them, he does what none but a sovereign may; for one may take the life even of a superior, but not give it ever except to an inferior.

1 Seneca, On Mercy, in MORAL EsSAYs 356, $371-73$ (J. Basore trans. 1970).

Another defense of freedom of expression that fits into this general strain of argumentation, though 
B.

To understand Meiklejohn's argument helps to point up, by contrast, that of Holmes, whose intellectual values, while no less universal in character and no less implicated in his defense of free speech than those of Meiklejohn, were nonetheless strikingly different. Meiklejohn properly sensed the difference, though he seemed throughout much of the essay to be confused about the real point of disagreement. Many had attacked Holmes, and his principal defender, Chafee, for harboring too great an attraction for free speech. But no one, until Meiklejohn, had really attacked the intellectual framework that underlay Holmes' defense of free speech.

Meiklejohn had difficulty, however, in locating the true conflict between himself and Holmes. He spent too much time denouncing Holmes for the clear and present danger test, which Meiklejohn seemed to misunderstand. $\mathrm{He}$ bridled at the suggestion that whenever speech became dangerous, the government could intervene and call a halt to further discussion. Purporting to be an advocate of an "absolute" standard for public expression, Meiklejohn appeared to stand for a more rigid level of protection. But the difference was more apparent than real: Meiklejohn was able to distance himself from Holmes only by exaggerating the actual meaning of the clear and present danger test, by making no allowance for the shift in Holmes' thought in the years between Schenck ${ }^{61}$ and Whitney, ${ }^{62}$ and by failing to acknowledge the flexibility inherent in his own "absolute" standard. By the end of the discussion, which begins with a severe castigation of Holmes and his test, Meiklejohn is basically in agreement with the reformulation of the clear and present danger test that Brandeis announced in Whitney (with, of course, Holmes' concurrence). ${ }^{63}$ Thus, one is left puzzled as to why Holmes is the "villain of the piece," when the only fault finally attributed to him is that he had earlier announced an overly broad principle, which, though it took him a few years to do so, he did ultimately get right. Even if it were true that "the great majority of [Holmes'] colleagues were taking very seriously the assertion of $\mathrm{Mr}$. Holmes that whenever any utterance creates clear and present danger to the public

it is virtually always lumped together with other dissimilar defenses, is that attributed to Thomas Jefferson: "If there be any among us who would wish to dissolve this Union or to change its republican form, let them stand undisturbed as monuments of the safety with which error of opinion may be tolerated where reason is left free to combat it." Jefferson, First Inaugural Address (March 4, 1801), reprinted in THE COMPLETE JEFFERSON 384, 385 (S. Padover ed. 1943). Toleration becomes proof-a "monument" - of one's confidence, security, and authority.

61 Schenck v. United States, 249 U.S. 47 (1919).

62. Whitney v. California, 274 U.S. 357 (1927).

63. See A. MEIKLEJOHN, supra note 8 , at 48 . 
safety, that utterance may be forbidden and punished," unfair to lay all the blame on Holmes, all the more so when it is conceded that "[n]o one, of course, believes that this is what Mr. Holmes intended ... to say" and that Holmes "spoke out with insistent passion" as his colleagues misinterpreted and misapplied his unfortunate test. ${ }^{65}$

This nondispute is representative of a good deal of misdirection in free speech argument. Like so much of the debate over the utility and meaning of the clear and present danger test and the so-called "absolute" standard, one comes away from these vigorous exchanges puzzled by what the fury is all about. Meiklejohn's tussle with Holmes suggests that what appears on the surface as vigorous disagreement over tests and standards is often only a superficial disagreement actually motivated by deeper and more fundamental disagreements about basic intellectual values.

A more careful reading of Meiklejohn is therefore required to understand the real and profound differences between him and Holmes. The disagreement centers not on whether or not to protect certain speech, but on the issue of the "moral and intellectual foundations of a self-governing society." Meiklejohn's commitment to and confidence in community values run squarely into Holmes' proclamations of ultimate relativism in human affairs. The dispute is about basic intellectual values, which inform the recommendation of tolerance in each instance.

Holmes' writings on the First Amendment reflects his well-known skepticism. ${ }^{67}$ The clearest and most celebrated of these statements is in his Abrams dissent, where he addressed the "logical" impulse to intolerance:

Persecution for the expression of opinions seems to me perfectly logi-

64. See id. at $45-46$.

65. See id. at 46.

66. See id. at 61 .

67. For a more extended analysis of Holmes' legal attitudes in general, see Rogat, The Judge as Spectator, 31 U. CHI. L. REV. 213 (1964). Professor Rogat portrays Holmes as "detached" "disengaged," and without concern for the way of life he believed in. "To a remarkable degree," Rogat writes, "Holmes simply did not care." Id. at 255. He would "bow to the way of the world," because his view was that power lay at the root of human affairs and power was not negotiable. Rogat presents this picture as a contrast to the common view of Holmes as "sceptical" and "humble." "He may have said that nothing was true once and for all, but on any particular occasion in making any particular decision he was convinced that he was right." Id. at 251 . His acquiescence, his faialism, his detachment, and his lack of caring are what led him to perform his judicial functions as he did with such tolerance.

What I am saying here in one sense conflicts with Professor Rogat's description and in another sense does not. It seems possible for someone like Holmes to believe quite deeply in the truth of his beliefs and yet to assume a position of tolerance towards contrary beliefs while still "caring" about his own beliefs. It is certainly possible for a person to feel the intensity of belief and simultaneously think that it is folly to feel that way, to recommend to oneself and to others that the preferable course is that which is contrary to one's nature. The problem may lie in the ambiguity of the idea of skepticism. There are people who appear to believe virtually nothing quite easily, and there are also people who believe most fervently and yet realize that those inclinations are without rational foundation and try on that basis to modulate them. 
cal. If you have no doubt of your premises or your power and want a certain result with all your heart you naturally express your wishes in law and sweep away all opposition. To allow opposition by speech seems to indicate that you think the speech impotent, as when a man says that he has squared the circle, or that you do not care whole-heartedly for the result, or that you doubt either your power or your premises. But when men have realized that time has upset many fighting faiths, they may come to believe even more than they believe the very foundations of their own conduct that the ultimate good desired is better reached by free trade in ideas-that the best test of truth is the power of the thought to get itself accepted in the competition of the market, and that truth is the only ground upon which their wishes safely can be carried out. ${ }^{68}$

Like so many of Holmes' remarks, this quotation has a strange mix of bluntness and ambiguity. While it appears to affirm the possibility of "truth" in human affairs, it does so by foreclosing any meaningful role for the individual other than as a component in a larger marketplace. It instructs us that wanting to believe in the truth of our beliefs is a natural aspect of the human condition, but urges us to overcome that tendency. So many "fighting faiths" have come to nought, it is said, that it is inadvisable to accept the validity of anything we happen to believe at the moment. We had best put our faith in the outcome of the market, a secular analogue of the comforting illusion of prior centuries that the king spoke with divine authority.

Ultimately, the intellectual posture advocated by Holmes was as encompassing as that offered by Meiklejohn, though fundamentally at odds with it. For both men, the protection of extreme speech took on special meaning. While Meiklejohn viewed tolerance as an affirmation of belief, Holmes viewed it as a necessary consequence of self-doubt. For Holmes, the more unbelievable the idea, the more the capacity for self-doubt was tested.

The intellectual posture of Holmes has been strikingly reinforced in recent years by Professor Gunther's publication of an exchange of letters during the Schenck ${ }^{69}-A b r a m s^{70}$ period between Holmes and Judge Learned Hand, who appeared to share much of Holmes' intellectual outlook. ${ }^{71}$ Responding to a letter by Hand in which Hand declares that "Tolerance is the twin of Incredulity," Holmes writes that he "agree[s] with it throughout." In the course of the letter he describes himself as

\footnotetext{
68. Abrams v. United States, 250 U.S. 616, 630 (1919) (Holmes, J., dissenting).

69. Schenck v. United States, 249 U.S. 47 (1919).

70. Abrams v. United States, 250 U.S. 616 (1919).

71. Gunther, Learned Hand and the Origins of Modern First Amendment Doctrine: Some Fragments of History, 27 STAN. L. REV. 719 (1975).
} 
being committed intellectually to a course of self-doubt, however unsuccessful the effort to fulfill that commitment: "When I say a thing is true I mean that I can't help believing it-and nothing more. But as I observe that the Cosmos is not always limited by my Cant Helps I don't bother about absolute truth or even inquire whether there is such a thing, but define the Truth as the system of my limitations."'72

Meiklejohn detected the intellectual ethic of relativism in Holmes' claim for free speech and perceived some of its implications. He found in Holmes' view "no adequate account of the deeper social ends and ideas upon which the legal procedure depends for life and meaning." He saw Holmes' attitude as "representative . . . of his time and country," a state of mind that Meiklejohn argued was culturally debilitating. Importantly, he saw a connection between the attitudes embodied in the principle of free speech and the attitudes people generally bear. And so he charged that Holmes' relativism had contributed to an excessive "individualism" in the country, and worse, an "intellectual irresponsibility" where "private interest" is given free reign under the rationalization that the "competition of the market" will shed the bad and save the good. It was a license to forego the burdens of intellectual effort and objective truth for the simpler and attractive path of self-preference. ${ }^{73}$

The conflict over the meaning of free speech between Meiklejohn and Holmes was rooted in a shared effort to develop a capacity reflected in the act of tolerance, but for one it was the capacity of shared belief and community, while for the other it was the capacity of self-doubt and individualism. One theory was centripetal, the other centrifugal.

II.

In the foregoing discussion, I have attempted to identify the conflicting intellectual values underlying two of our major theoretical accounts of free speech. At the risk of being excessively reductionist, I have suggested that the difference between Meiklejohn and Holmes is that for one tolerance constitutes the affirmation of a belief or set of beliefs and for the other tolerance is acknowledgement of self-doubt or relativism. For both, the legal concept of free speech provides an opportunity to instill or create a particular intellectual outlook. The activity of speech itself is not the end to be secured, but rather the reformation of perceived undesirable intellectual tendencies and the substitution of other tendencies.

Reduced to these terms, this dispute can be found replicated elsewhere in the classic free speech literature. This is, for example, the basic division

72. Id. at 757 .

73. See A. MEIKLEJOHN, supra note 8, at 73-74. 
in argument that Mill uses in constructing his plea for liberty of speech. His question is this: Should one think of one's beliefs as "true," but nevertheless be tolerant of the expression of untruths, or should one think of them as potentially untrue and proceed to justify tolerance on that basis? Despite the inconsistency of the two premises for a free speech theory, Mill advanced both as alternative grounds. More recently, one finds this tension between competing bases for tolerance reproduced in Bickel's last book, The Morality of Consent, ${ }^{\mathbf{7 4}}$ where the argument vacillates between a plea for a Burkean acceptance of life without universal truths and a recognition of the destructiveness of relativism and the corresponding need for deeply embedded community values.

Neither defense of tolerance, I would contend, provides an acceptable or stable foundation for free speech. I return to Meiklejohn and Holmes to demonstrate the proposition. Both are doomed to fail because what each offers is unacceptably extreme as a general intellectual posture and, with respect to the actual functioning of free speech, is built upon an internal contradiction. Each presents a vision that is appealing but dangerously partial.

Consider Meiklejohn. He presents an attractive vision of the self-governing community, modeled on an idealized New England town meeting where people carry on under a set of shared values that includes a belief in the capacity for self-control (self-determination) and a belief in the spirit of cooperative striving for the general interest. It would be comforting to know what you believed, to be confident of the bases and reasons for your belief, and to feel in control of your capacity to recreate the environment to correspond to those beliefs. But such a world can itself be undermined by speech. Meiklejohn says it is a function of the First Amendment to let those members of the community who have arrived at a "truth" communicate it to others. But suppose they do so and it is not received by others as a truth at all, but as a falsehoood? In a self-governing society, people then face a dilemma when they believe deeply in the truth of some idea, yet others do not appear to share the same feeling.

Meiklejohn himself reveals the fragility of a position of tolerance constituted on a foundation of right belief. At the very end of the essay, he rues the lack of opportunity to apply his theory to concrete examples of the limits of free speech. He finds it "essential, however, to mention one typical failure [of our national education] which, since it has to do with the agencies of communication, falls within the field of our inquiry." The "failure" is "commercial radio." Here was a "new form of communication" that had "opened up before us the possibility that, as a people living

74. A. BICKEL, supra note 11 , at 3-30. 
a common life under a common agreement, we might communicate with one another freely with regard to the values, the opportunities, the difficulties, the joys and sorrows, the hopes and fears, the plans and purposes, of that common life." Perhaps, he says, "amid all our differences, we might become a community of mutual understanding and of shared interests." 75

"But never was a human hope more bitterly disappointed." While in the beginning it deserved the protection of the First Amendment, it was not "entitled" to it now. Why not? Because "[i]t is engaged in making money." Radio "is not cultivating those qualities of taste, of reasoned judgment, of integrity, of loyalty, of mutual understanding upon which the enterprise of self-government depends. On the contrary, it is a mighty force for breaking them down. It corrupts both our morals and our intelligence."

Here in one surprising passage, Meiklejohn reveals the limits of the concept of the "right to hear," of the notion that free speech means that we are not "afraid" of dangerous ideas, that "to be afraid of any ideas, any idea, is to be unfit for self government." ${ }^{37}$ In the end, according to Meiklejohn, we cannot afford to tolerate all forms of "subversive" speech, but only those forms that are not really dangerous because the vast majority already dislike them. In the quest for values through enforced toleration, the values can so easily end up taking precedence over the idea of toleration itself. As with Rousseau's famous turnabout on the meaning of civil religion, Meiklejohn's "public interest" notions become subtly transmuted into a justification for suppression.

But the alternative of self-doubt bears its own seeds of instability. It moves easily (as Meiklejohn said) into a posture of nihilism and self-interest that erodes social cohesion. ${ }^{78}$ Yet its problems as a foundation for free speech are even more fundamental. Perhaps the individual can tenably accept toleration on the conviction that nothing is true, but his actions become much less defensible when he employs the power of the state to inhibit others from being intolerant. In this instance, the individual is demanding an intellectual outlook of self-doubt from those who wish to insist on belief. The question may properly be asked why the belief that

75. A. MEIKLEJOHN, supra note 8 , at $86-87$.

76. Id. at 87 .

77. Id. at 28 .

78. Professor Bickel wrote:

This is the point at which one asks whether the best test of the idea of proletarian dictatorship, or segregation, or genocide is really the marketplace, whether our experience has not taught us that even such ideas can get themselves accepted there, and that a marketplace without rules of civil discourse is no marketplace of ideas, but a bullring.

A. BICKEL, supra note 11 , at 76-77. 
"the ultimate good desired is better reached by free trade in ideas" should not be subjected to the same self-critical realization that "time has upset many fighting faiths." If we are better off permitting the "play of forces" and supremacy through "free competition," then why should the same evolutionary process not play itself out in the arena of speech as well?

The attitude reflected in these rhetorical questions can be found in Holmes' early free speech decisions, like Schenck, where tolerance is expressed as the need for judicial acceptance of a nation driven to intolerance by war-generated passionate convictions of true belief. ${ }^{79} \mathrm{I}$ find it a more congenial hypothesis that Holmes' dramatic change of position on free speech between Schenck and Abrams was not merely an unsuccessful strategy employed in Schenck to get a good test at the expense of affirming a conviction, or the result of an interim education in the merits of free speech, but rather was the natural, perhaps inevitable, shifting about on a position premised on the sands of relativism and self-doubt. ${ }^{\mathbf{8 0}}$

It is clear that Holmes was himself uncertain about the appropriate implications to be drawn from acknowledgment of a relativistic universe. In a letter to Judge Hand discussing his thoughts before "the statue of Garrison on Commonwealth Avenue, Boston," Holmes says that if he were "an official person I should say nothing shall induce me to do honor to a man who broke the fundamental condition of social life by bidding the very structure of society perish rather than he not have his way-Expressed in terms of morals, to be sure, but still, his way." As the "son of Garrison," alternatively, he should find himself thinking differently, taking the view that "every great reform has seemed to threaten the structure of society,- -but that society has not perished, because man is a social animal, and with every turn falls into a new pattern like the Kaleidoscope." As a philosopher, however, he would believe them to be "[f]ools

79. "When a nation is at war many things that might be said in time of peace are such a hindrance to its effort that their utterance will not be endured so long as men fight and that no Court could regard them as protected by any constitutional right." Schenck v. United States, 249 U.S. 47, 52 (1919).

80. See Gunther, supra note 71, at 719; Chafee, supra note 38 , at 900-01.

It is worth noting here that Learned Hand seems to have developed a similar turnabout in his lifetime on the matter of judicial enforcement of free speech protection for radical expression, just as Holmes did. The only difference is that his reversal of position went the opposite way from that of Holmes. Hand began as a fervent supporter of liberal free speech doctrine with his well-known decision in Masses Publishing Co. v. Patten, 244 F. 535 (S.D.N.Y.), rev'd, 246 F. 24 (2d Cir. 1917), from which the so-called "incitement test" was derived, but ended up striking a very conservative posture with his opinion in United States v. Dennis, 183 F.2d 201 (2d Cir. 1950), affd, 341 U.S. 494 (1951) -a view of free speech he embraced personally in his 1958 Holmes Lectures, see L. HAND, THE BILL OF RIGHTS (1958), in which (in Professor Gunther's characterization) he viewed "the first amendment as one of a set of moral adjurations, not as a judicially enforceable norm," Gunther, supra note 71 , at 752. What is especially interesting is that "Hand and Holmes shared a common philosophical outlook," which included a disbelief "in absolutes or eternal truths" and a commitment to "skepticism." Id. at 732-33. To Hand, "Tolerance is the twin of Incredulity," id. at 736, and "our chief enemies are Credulity and his brother Intolerance." Id. at 766. 
both, not to see that you are the two blades (conservative and radical) of the shears that cut out the future." But, it is the "ironical man in the back of the philosopher's head" who is given the last word, saying of the philosopher that he was the "[g]reatest fool of all" for not seeing that "man's destiny is to fight" and urging him to "take thy place on the one side or the other, if with the added grace of knowing that the Enemy is as good a man as thou, so much the better, but kill him if thou Canst." ${ }^{\text {"1 }}$ Holmes himself could only embrace his own skepticism with misgiving and doubt.

III.

We can agree with Kalven that at its core the First Amendment prohibits the government from severing a democratic relationship with the citizenry by instituting a regime of seditious libel. And New York Times Co. v. Sullivan is a case that evokes this kind of First Amendment imagery-even if the reality was quite distant from it. But the securing of that victory did not complete the role to be played by the First Amendment. It only initiated it. For the idea of free speech, at least as it has come to be known in this century, addresses far broader questions: It speaks to the intellectual make-up and character of the society.

As such, free speech is a far more complex enterprise than preventing governmental interference in the democratic process, maximizing the flow of data, or protecting the rights of speech for minorities against tyrannical majorities. Meiklejohn and Holmes offer competing intellectual bases for free speech. Each proves unacceptably limited. To broaden the inquiry into the role of free speech as a forum for defining certain fundamental intellectual values is to begin to build a foundation from which we can better evaluate our previous experience with the concept and perhaps even develop a more coherent and stable general theory.

One might, for example, reconsider the differences between two cases such as Sullivan and Cohen. Is the primary difference that Sullivan defines free speech in terms of seditious libel, offering a systemic vision in which the discussions of the citizens are protected by the courts against governmental hindrance, while Cohen defines it more in terms of a speaker's right to self-fulfillment? I think not. The most important differences between those two major opinions is in the intellectual attitudes that each suggests, both implicitly and explicitly.

In Sullivan, the Court was fundamentally in sympathy with the message of the speech at issue. Indeed, this message of racial equality was one that the Court itself had fostered in the face of severe criticism. First, the Court offered encouragement for speech and its use for promoting beliefs.

81. Id. at 757. 
The Court began with the "profound national commitment to the principle that debate on public issues should be uninhibited, robust, and wideopen," ${ }^{82}$ words that in context conveyed the tone of support for dissent. This theme was then developed with an apologia for belief's natural tendency toward excess. The Court quoted an earlier decision where it was said of religious and political views that "[ $t$ ]o persuade others to his own point of view, the pleader, as we know, at times, resorts to exaggeration, to vilification of men who have been, or are, prominent in church or state, and even to false statement." ${ }^{283}$ The notion that the prerogatives of belief must be respected was then restated at the end of the analysis-and with new meaning-with a description of the Court's own posture of self-restraint in the face of harsh criticism. The "concern for the dignity and reputation of the courts," the Court had held, "does not justify the punishment as criminal contempt of criticism of the judge or his decision," even if the "utterance contains 'half-truths' and 'misinformation." "84 This is because judges "are to be treated as 'men of fortitude, able to thrive in a hardy climate. ..." "B5 The suggestion is not that speech is a rich source of potential ideas, or that criticism might be helpful in arriving at the correct result, but rather that speech is something to be tolerated with "fortitude." The overtones are again ones of firmness of conviction, and they converge with the earlier sympathetic explanation in the opinion about the particular speech challenged in the case. In the end, Sullivan is an opinion that defines tolerance in terms of the encouragement and affirmation of belief.

The Court in Cohen $^{86}$ also explored how communication or speech activity ought to be regarded, though there the context was the more traditional one in which the Court itself disagreed with the particular exercise of speech at issue. The opening sentence of the opinion unambigiously stated that though "[t]his case may seem at first blush too inconsequential to find its way into our books, . . . the issue it presents is of no small constitutional significance." abuse of a right was gradually made plain, first as Harlan refrained from restating Cohen's slogan and then as he heaped scorn through elegant

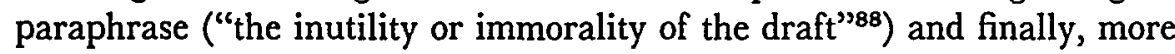
explicitly, when he labeled the speech as a "distasteful mode of expres-

82. New York Times Co. v. Sullivan, 376 U.S. 254, 270 (1964).

83. Id. at 271 (quoting Cantwell v. Connecticut, 310 U.S. 296, 310 (1940)).

84. Id. at 272-73 (citations omitted).

85. Id. at 273 (quoting Craig v. Harney, 331 U.S. 367,376 (1947)).

86. Cohen v. California, 403 U.S. 15 (1970).

87. Id. at 15 .

88. Id. at 18 . 
sion," "a crude form of protest," of individual distasteful abuse of a privilege."'1

Having thus characterized the speech activity, the question then became how to vindicate its toleration. As with Sullivan, the messages were mixed. On the one hand, it was said that this seeming "verbal cacophony is not a sign of weakness but of strength." more skeptical than anything encountered in Sullivan: The speech could not be excised because "while the particular four-letter word being litigated here is perhaps more distasteful than most others of its genre, it is nevertheless often true that one man's vulgarity is another's lyric." ${ }^{\text {93 }} \mathrm{Co}$ hen arose, in the end, more from Holmes' intellectual perspective. The activity was distasteful, but Harlan was reluctant to coerce on the basis of his aesthetic predilections.

This discussion is not intended to be a definitive interpretation of either decision, but only an illustration of the way in which we might assess the impact and message of particular cases and thus establish a critical perspective. Beyond that, however, we might also begin to develop a better and more viable theory of what free speech ought to do. Everyday experience tells us that discussion can enhance our knowledge and understanding of the world, and of the political realm too, and that to express oneself is at a certain level an elemental need of the personality. To agree with these assertions, however, does not take us far in answering the questions: Why has the society singled out the activity of speech for such special attention and held the community to what can only be regarded as an extreme position of self-restraint and tolerance? To say that speech is useful and important is a beginning, but it hardly begins to account for what is done in fact in the name of free speech.

Answers to these basic questions emerge from the preceding discussion about the writings of Meiklejohn and Holmes, and I would like to conclude with a brief outline of how those answers can provide a foundation for a free speech theory. In doing so, let us continue working with the concept of free speech as concerned with the "process" of social decisionmaking. The intellectual history of the idea of free speech in this century has been dominated by this concept and, as I have suggested, the concept has serious deficiencies. The idea of free speech has often been coupled with the disingenuous notion that courts are only protecting that process from government intervention while, in fact, they have intruded into it.

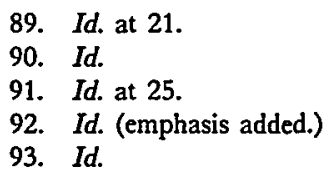


The idea has been tied excessively to the process of political decisionmaking instead of being envisioned more broadly as encompassing decisionmaking on all social values. And the idea has been narrowly conceived as concerned only with the maximization and distribution of information instead of with the qualitative issues of what I have referred to here as intellectual values. But, despite these deficiencies, there remains something powerfully attractive and worthwhile in thinking about free speech as an institution where the way in which social issues are addressed and resolved is itself considered.

This way of thinking about free speech does not, however, help to account for why speech is treated differently from other conduct when issues of social organization are raised. The common view is to claim that speech is properly singled out for special protection because it is uniquely valuable as a means of conveying necessary information for social decisionmaking. Such an answer, however, proves inadequate. An interest in acquiring relevant information cuts far more broadly through human activity, encompassing nonspeech conduct as well as speech. Indeed, the recent movement in free speech jurisprudence to recognize a right to gather information is itself premised on a belief that nonspeech conduct is vitally related to the acquisition and distribution of relevant information. The conventional justification, moreover, loses its integrity as speech becomes more extreme in character, as the social harm reasonably thought to arise from it increases. I agree with those who have objected to the argument that all that has been done in the name of free speech is justified by its informational value, and I do not believe that either Holmes or Meiklejohn saw the justification for toleration in those limited terms. At some point, speech becomes simply a matter of human behavior like any other, all of which is open to processes of social decisionmaking. And at that point, what can be the justification for further exempting speech behavior from the process?

An answer rests on the earlier discussion about the character, or quality, of social decisionmaking, and about the intellectual values that are said to be important to it. Meiklejohn and Holmes were responding not to some single-minded urge for information but to the perceived need to correct what might be thought of as a bias or deficiency in the way people think about issues when engaged in the social process. Such a bias could be found in social decisionmaking about every issue, whether it concerns the limits of speech or nonspeech conduct. But, it is the area of speech that has been seized as presenting the opportunity for identifying and addressing that deficiency. Since under either Meiklejohn's or Holmes' view, this deficiency in social discourse manifests itself in a tendency to excessive intolerance of speech, speech must be treated as a portion of behavior that 
is excluded from the social decisionmaking process. Toleration must be pushed to an extreme, as a kind of opportunity to point up and address what is in fact a broader problem. In an important sense, then, it can be said that free speech has gone beyond process in an attempt to shape the nature of that process. Free speech becomes a concept under which an area of social organization is effectively carved out and rendered immune, not for its uniquely important role in assisting decisionmaking, but as a way of pressing for an intellectual capacity or perspective that is also thought to be of direct value elsewhere.

It is important to recognize the significance of the change in orientation involved in this way of looking at free speech. The writings of Holmes and Meiklejohn are representative of an extremely important but generally unnoticed shift in perspective on the meaning and function of the free speech principle. No longer is the premise of the discussion about free speech the assumed need to secure "our" liberty to speak freely against some "other" antagonistic political body or power. The center of focus has shifted away from the purpose of establishing an unrestricted zone of liberty in which we can fulfill "our" interests to speak and to hear the information and ideas we value - what Isaiah Berlin referred to as the idea of "negative liberty" - towards the purpose of creating a zone of unregulated behavior against which "we" can test and develop a general character of mind through confrontation with that behavior-what may be thought of as the goal of exploring the virtues of tolerance. In a sense, this latter ambition or aspiration can itself be thought of as a variation of that ambiguous concept "liberty"; indeed, it seems to resemble what Berlin classified as the notion of "positive liberty", that is, the "wish on the part of the individual to be his own master." According to Berlin, the mastery sought may be over "external forces" or over irrational passions and impulses internal to the individual or community ${ }^{95}$ In envisioning these two divergent components of the concept of liberty, Berlin worried about the

94. I. BERLIN, Two Concepts of Liberty, in FOUR ESSAYS ON LIBERTY 118, 122-31 (1969).

95. Id. at 131. The primary discussion of "positive freedom" appears at 131-134. It is also interesting to note in this context that one can detect in Meiklejohn's arguments for toleration, as I have described them, the use of what Berlin referred to as the "search for status." Id. at 154-162. This particular desire in human beings for "status," Berlin argued was something distinguishable from the concept of freedom or liberty:

It is something no less profoundly needed and passionately fought for by human beings-it is something akin to, but not itself, freedom; although it entails negative freedom for the entire group, it is more closely related to solidarity, fraternity, mutual understanding, need for association on equal terms, all of which are sometimes-but misleadingly-called social freedom.

Id. at 158. The need for fraternity and status, Berlin contended, had frequently led in human affairs to the curtailment of true liberty, though it was often confused with the idea of liberty or placed under the liberty banner. But with Meiklejohn we see how the tapping of the desire for community and fraternity and equality of status can be the rallying call for toleration as well as for revolution, or for submission to tyranny. 
positive conception being turned into a source of oppression, a concern to which the discussion here lends weight. What he did not see, however, is how the two conceptions of negative and positive freedom could be yoked together, the former in service to the latter; how the establishment of a zone or field of "negative" freedom could become a source or method of striving for some sense of "positive" liberty. Brandeis actually gave hints of it many years ago in Whitney, where amidst a litany of possibilities about the meaning and function of free speech he wrote: "Men feared witches and burnt women. It is the function of speech to free men from the bondage of irrational fears."

To be sure, we are still left with a number of important questions. Is such a view of the functions of free speech justified? Is defining and attempting to encourage the development of intellectual values a proper role for courts to play? Does one's talk of intellectual values push beyond the boundaries of the notion of process and determine substance and outcome? Are the assumptions about the nature of mind correct? How far and in what ways do the perceived problems in the intellectual make-up of people cut through the activities of society? What are the intellectual values we should be seeking?

I do not possess a clear set of answers to these questions and I shall leave them for another time. I do not know, for instance, how to define in a paragraph the intellectual values that ought to inform our social decisionmaking. I do think, however, that a stance of relativism or of right belief, even when coupled with tolerance, will not provide a satisfactory foundation.

But, these remaining difficulties ought not to obscure the importance of the more fundamental observations about the functions of free speech, which provides a structure for inquiry. Free speech is a social context in which basic intellectual values are developed and articulated, where assumptions about undesirable intellectual traits are offered and remedies proffered. Both Meiklejohn and Holmes spoke to these issues. Though I have argued that both ultimately failed in their efforts to define a set of intellectual values for society through free speech, the failure in each case was only partial and due to the universality each sought for his own paradigm.

96. Whitney v. California, 247 U.S. 357, 376 (Brandeis, J., concurring). 


\section{The Yale Law Journal}

Volume 92, Number 3, January 1983

\section{Richard L. Revesz Editor-in-Chief}

\author{
Steven G. Calabresi \\ Note \& Topics Editor \\ José M. Berrocal \\ Davison M. Douglas \\ Cynthia L. Estlund \\ Garl H. Loewenson, Jr. \\ Note Editors
}

Robert E. Cooper, Jr. Managing Editor

Martha Grace Duncan George Ellard

Michele S. Hirshman

Eric L. Lewis

H. J. van der Vaart

Article \& Book Review Editors
David E. Brodsky

Sarah Dillian Gohn

Nicholas M. De Feis

Doron A. Henkin

Candice Hoke

C. Bruce Baker

Thomas H. Bell

Michael T. Brady

Troy Brennan

David A. Broadwin

Peter W. Devereaux

Stephen W. DeVine

Joseph A. Franco

Roger George Frey

Nancy I. Greenberg
Michael A. Jacobs

Valerie A. Lambiase

Janet R. Langford

Gene J. Oshman

\section{Senior Editors}

David A. Hansell

Joan E. Hartman

Eugene G. Illovsky

Samuel Issacharoff

Roberta M. Kania

Andrew A. Lance

Gary S. Lawson

Peter B. Marrs

Meridee Moore

Susan R. Necheles

Daniel R. Ortiz
Robert D. Richman

William H. Rooney

Victoria P. Rostow

Don Sparks

Wendy Warring

Linda M. Owens

Wes Parsons

Patrice M. Pitts

Manley W. Roberts

Bennett C. Rushkoff

Jeffrey W. Sacks

Daniel Smirlock

Pat Shapiro Spengler

Susan J. Swift

Gene A. Turk, Jr.

Editors

Business Manager: Pamela Standish

Editorial Assistant: Claudia Shapiro

\section{Student Contributors to This Issue}

Roger George Frey, The Guilty But Mentally III Verdict and Due Process

William H. Rooney and Don Sparks, The Constitutional Dimensions of Student-Initiated Religious Activity in Public High Schools

Daniel Smirlock, "Clear and Convincing" Libel: Fiction and the Law of Defamation 